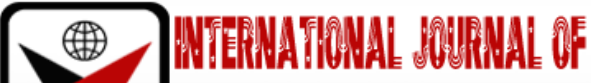

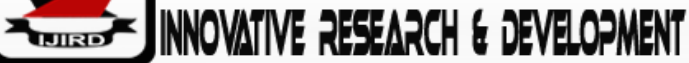

ISSN 2278-0211 (Online)

\section{Analysis of Level of Awareness of Health Risks Associated with Egg Donation among Female Undergraduates of Universities in Agbani Education Zone, Enugu State, Nigeria}

Dr. Nweze, Sylvester Onuegbunam
Gynaecologist, Department of Obstetrics and Gynaecology,
Enugu State University of Science and Technology Teaching Hospital, Enugu, Nigeria
Iheanacho Ifeoma Loveth
Ph.D. Student, Department of Health and Physical Education,
Enugu State University of Science and Technology, Enugu, Nigeria
Dr. Ani, Ngozi Rita
Associate Professor, Department of Health and Physical Education
Enugu State University of Science and Technology, Enugu, Nigeria
Dr. Ezenwaeze, Malachy Nwaeze
Senior Registrar, Department of Obstetrics and Gynaecology
Enugu State University of Science and Technology Teaching Hospital, Enugu, Nigeria

\begin{abstract}
:
Background: Egg donation is the process by which a woman donates eggs to enable another woman to conceive as part of an assisted reproduction treatment or for biomedical/scientific research

Aim:The purpose of the study was to investigate level of awareness of health risks associated with egg donation among female undergraduates of Universities in Agbani Education Zone of Enugu State.

Methods: This cross-sectional descriptive study involved 387 female undergraduates of universities in Agbani education zone, Enugu State. A combination of Muti-stage and systematic random sampling method were used in selecting two Universities and recruitment of 387 female undergraduates respectively for the study. Self-administered questionnaire was used for data collection. Data generated were analyzed using statistical package for social science version 23 and presented in frequency tables and percentage scores.

Result: The results of data analysis emanating from the study showed that Female undergraduates of universities in Agbani Education Zone of Enugu State had low level of awareness of health risks associated with egg donation. $57.36 \%$ had moderate level of awareness of physical health risks associated with egg donation, $37.61 \%$ had low level of awareness of social health risks associated with egg donation, while $39.41 \%$ had low level of awareness on mental health risks associated with egg donation. On awareness of procedure involved in egg donation, similarly low level of awareness was the case, and findings also shows that an overwhelming majority of the respondents were not familiar with the term egg donation for scientific research purposes and a little knew about egg donation for ART

Conclusion: It was concluded that there is generally low level of awareness of health risks, as well as procedures associated with Egg Donation among Female undergraduates of Universities in Agbani Education Zone of Enugu State.
\end{abstract}

Keywords: Health, Risks, egg donation, female undergraduates of universities

\section{Introduction}

Egg donation is the process by which a woman donates eggs to enable another woman to conceive as part of an assisted reproduction treatment or for biomedical/scientific research [1]. Egg donation has been in practice for several years [2]. The woman who offers the egg is called the giver/donor [3]. The harvesting of donor's egg is a complicated and intricate process [4]. The first step in the egg donation process is the recruitment of a donor preferably under age 30 [ 5-9]. The recruitment practices range from private egg brokers to medical centers with affiliated fertility clinics to free standing independent fertility centers [10]. Enticing monetary offers of generous compensation usually prompt the prospective donor to contact fertility centers.

Egg donation is used in two forms; for Assisted Reproduction Technology and for Somatic Cell Nuclear Transfer (SCNT). Assisted reproduction with egg donation has become a recent form of procreation. Although the family may be non-traditional, egg donation provides an opportunity for single women, infertile women, as well as the gay, lesbian, 
bisexual and transgendered (GLBT) community to create their own definition of family [3]. This process removes procreation from bedroom to clinic. Approximately, 10.5\% of Assisted Reproductive Technology(ART) in the United States use eggs from donors [11]

At present, there is no law governing the practice of ART in Nigeria despite the relatively long duration of practice[7]. Because of lack of national regulatory agencies in most developing countries, most IVF clinics make their own rules and follow different standards [7]. This shows that egg donation practice, safety and quality assurance of the process is in great dilemma nevertheless, young women and childless couple see it as a way out to settle their different predicament.

Somatic cell nuclear transfer (SCNT) is the process of combining two cells for the purpose of growing one cell with particular genetic characteristics [10]. It is noted that Oocytes are needed for controversial cloning research which appears to be the reason interest groups and legislators have enacted a special compensation rule for oocyte donation for research [1]. However, [12], stated that since most women in the developed countries are not going to willingly endanger their lives to help advance the cloning technology, there is an acute need for Biotechnology companies to come into Africa and harvest the eggs of poor African women and leaving them in destitution. In support of the above statement, [1] also poised that in contrast to egg donors for reproduction purposes who tend to be white, well-educated and well paid, supporters of the bill argue that SCNT would turn to poor women who may disregard medical risks because of their need for money, this might inform the reason for increase in egg donation in Africa with particular reference to Nigeria. In line with the above argument, it is well noted that there is high quest for human egg for possible IVF and SCNT research which has given rise to young vulnerable poor or not well-informed women being coarse to donate egg in order to make money not considering their health (social, physical, mental), the procedure involved, cultural and ethical implication associated with egg donation.

\subsection{Problem Statement}

Buying and selling of human egg has become one of the recent public health concerns and the practice has generated worldwide discussion involving its ethical, physical, social and health risks as regards to the egg donor. Usually, young women between the ages of 21 to 28years are recruited by egg donor agencies for this, young women may be open to egg donation due to different reasons but mostly for financial reasons. Consequently, [4] noted that although the compensation of money is not life changing, selling one's eggs may be viewed as an easy way to make a lot of cash. Thus, enticing naive, undergraduate female students, who are in need of money, with financial rewards for their eggs are majorly at risk. Bearing in mind the present economic instability in the country, many ignorant women will be compelled to participate in the procedure in order to offset financial burden on them. These women usually pass many physical and medical examinations as well as an intelligent quotient (IQ) test. When a woman passes all the required examination, she is then recruited and egg donation process and procedures follow. However,[9] concluded with the notion that if selling of human organs is considered bad, perhaps the same status should be afforded to egg/sperm donations -- that is, neither should be allowed as salable goods in a free market system.

The process of egg donation can be rigorous and associated with many physical, social and mental health risks. Physical health risks will include feeling of self-devaluation, lack of self-confidence, victimization, fatigue, vaginal bleeding, hyper stimulation syndrome and infertility. The social health risks involved includes; commercializing of body parts liken to prostitution (since it involves selling of what ought to be given freely) and as well, regarded as modern-day slavery, feeling of self-devaluation, The mental health risks associated with egg donation includes loss of sleep, lack of selfconfidence, anxiety over future fertility, emotional adjustment, being anxious over one's genetic child and psychological discomfort

Therefore, this study aims at investigating the level of awareness of health risks associated with egg donation among female undergraduates of Universities in Agbani Education Zone of Enugu State.

\subsection{Aim}

The main purpose of this study is to investigate level of Awareness of Health Risks Associated with Egg Donation among Female undergraduates of Universities in Agbani Education Zone of Enugu State.

Specifically, the study sought to:

- Find out the level of awareness of physical health risks associated with egg donation among female undergraduates of Universities in Agbani Education Zone in Enugu State.

- Determine the level of awareness of social health risks associated with egg donation among female undergraduate of Universities in Agbani Education Zone in Enugu State.

- Investigate the level of awareness of mental health risks associated with egg donation among female undergraduates of Universities in Agbani Education Zone in Enugu State.

- Ascertain the level of awareness of procedures involved in egg donation among female undergraduates of universities in Agbani Education Zone in Enugu State.

\subsection{Research Questions}

The following research questions guided the study;

- What is the level of awareness of physical health risks associated with egg donation among female undergraduates of Universities in Enugu State?

- What is the level of awareness of social health risks associated with egg donation among female undergraduates of Universities in Enugu State? 
- What is the level of awareness of mental health risks associated with egg donation among female undergraduates of Universities in Enugu State?

- What is the level of awareness of procedures involved in egg donation among female undergraduates of Universities in Agbani Education zone in Enugu state?

\section{Methodology}

\subsection{Study Design}

This was a cross-sectional descriptive study that involved 387 female undergraduates of two universities in Agbani education zone, Enugu State, South East Nigeria.

\subsection{Study Area}

This study was carried out among female undergraduates of the two universities in Agbani education zone, Enugu State. Enugu state is one of the 36 States in the Nigerian federation and also one of the five States in the South-Eastern geopolitical zone of Nigeria. It lies partly within the semi-tropical rain forest belt of the South and has an area of about $7.161 \mathrm{~km}^{2}$. It has a population of 3,267,837 from 2006 Census ${ }^{50}$. About thirteen universities (both public and privates) are in operation in Enugu State

\subsection{Study Population}

This is made up of all the female undergraduates of the two universities in Agbani education zone, Enugu State who were sampled following consent to participate in the study.

\subsection{Study Sample}

A minimum sample size of 194 was calculated based on a prevalence awareness of health risks associated with egg donation of $18 \%$ from previous study but was upgraded to 387 to ensure more representative sample

\subsection{Sampling Technique}

A combination of Muti-stage and systematic random sampling method were used in selecting two Universities and recruitment of 387 female undergraduates respectively for the study. Self-administered questionnaire was used for data collection. Data generated were analyzed using statistical package for social science (SPSS) version 23 and presented in frequency tables and percentage scores.

\subsection{Inclusion/Exclusion Criteria}

Only the female undergraduates of the institutions who gave consent for the study were sampled. Those who failed to give consent were excluded

\section{Results}

\begin{tabular}{|c|c|c|c|c|c|c|}
\hline \multirow[t]{2}{*}{ Sn } & \multirow[t]{2}{*}{ Items } & \multicolumn{2}{|c|}{ True } & \multicolumn{2}{|c|}{ False } & \multirow[t]{2}{*}{ Decision } \\
\hline & & Freq. & $\%$ & Freq. & $\%$ & \\
\hline 1 & $\begin{array}{l}\text { hot flushes and sleep problems are physical } \\
\text { health risk associated with egg donation }\end{array}$ & 255 & $65.89 \%$ & 132 & $34.11 \%$ & HA \\
\hline 2 & $\begin{array}{l}\text { late menopause is one of the physical health } \\
\text { risks associated with egg donation }\end{array}$ & 231 & $59.69 \%$ & 156 & $40.31 \%$ & MA \\
\hline 3 & $\begin{array}{l}\text { excessive weight increase is not a physical } \\
\text { health risk associated with egg donation }\end{array}$ & 148 & $32.24 \%$ & 239 & $61.76 \%$ & LA \\
\hline 4 & $\begin{array}{l}\text { painful menstrual cycle is one of the reasons } \\
\text { young females participate in egg donation }\end{array}$ & 143 & $36.95 \%$ & 244 & $63.05 \%$ & LA \\
\hline 5 & $\begin{array}{l}\text { mood swings and fatigue are physical health } \\
\text { risk associated with egg donation }\end{array}$ & 247 & $63.82 \%$ & 140 & $36.18 \%$ & HA \\
\hline 6 & $\begin{array}{l}\text { cancer is one of the physical health risks } \\
\text { associated with egg donation }\end{array}$ & 265 & $68.48 \%$ & 122 & $31.52 \%$ & HA \\
\hline 7 & $\begin{array}{l}\text { hyper stimulation syndrome (OHSS) is a } \\
\text { major physical health risk associated with } \\
\text { egg donation }\end{array}$ & 296 & $76.49 \%$ & 91 & $\begin{array}{c}23 \\
\text { ww.51\% }\end{array}$ & HA \\
\hline 8 & $\begin{array}{l}\text { vaginal bleeding is not one of the physical } \\
\text { health risks associated with egg donation }\end{array}$ & 200 & $51.68 \%$ & 187 & $48.32 \%$ & $\mathrm{MA}$ \\
\hline 9 & $\begin{array}{l}\text { infertility is not one of physical health risks } \\
\text { associated with egg donation }\end{array}$ & 213 & $55.04 \%$ & 174 & $44.96 \%$ & MA \\
\hline & Average & 222 & $57.36 \%$ & 165 & $42.64 \%$ & MA \\
\hline
\end{tabular}

Table 1: Frequency and Percentage Scores of Levels of Awareness of Physical Health Risks Associated with Egg Donation among Female Undergraduates of Universities in Agbani Education Zone, Enugu State 
Average percentage score of $57.36 \%$ from table 1 showed that the female undergraduates of universities in Agbani Education Zone in Enugu State had moderate level of awareness on physical health risks associated with egg donation.

\begin{tabular}{|c|c|c|c|c|c|c|}
\hline \multirow[t]{2}{*}{ Sn } & \multirow[t]{2}{*}{ Items } & \multicolumn{2}{|c|}{ True } & \multicolumn{2}{|c|}{ False } & \multirow[t]{2}{*}{ Decision } \\
\hline & & Freq. & $\%$ & Freq. & $\%$ & \\
\hline 10 & $\begin{array}{c}\text { feeling self-devaluation is not a social } \\
\text { health risk associated with egg } \\
\text { donation }\end{array}$ & 181 & $46.77 \%$ & 206 & $53.23 \%$ & MA \\
\hline 11 & $\begin{array}{c}\text { future generation can be affected } \\
\text { socially through the practice of egg } \\
\text { donation }\end{array}$ & 66 & $17.05 \%$ & 321 & $82.95 \%$ & LA \\
\hline 12 & $\begin{array}{c}\text { one of the social vices of egg donation } \\
\text { is that it removes procreation from } \\
\text { bedroom to clinic }\end{array}$ & 97 & $25.06 \%$ & 290 & $74.94 \%$ & LA \\
\hline 13 & $\begin{array}{l}\text { egg donation does not negate the role } \\
\text { of motherhood }\end{array}$ & 255 & $65.89 \%$ & 132 & $34.11 \%$ & HA \\
\hline 14 & $\begin{array}{l}\text { Inter-marrying of unknown half- } \\
\text { siblings is one of the social health } \\
\text { risks associated with egg donation }\end{array}$ & 129 & $33.33 \%$ & 258 & $66.67 \%$ & LA \\
\hline 15 & $\begin{array}{l}\text { loss of cultural and genetic traits is } \\
\text { not among the consequences of egg } \\
\text { donation }\end{array}$ & 160 & $41.34 \%$ & 227 & $58.66 \%$ & MA \\
\hline 16 & $\begin{array}{l}\text { not being a biological parent to one's } \\
\text { offspring is a major social health risk } \\
\text { associated with egg donation }\end{array}$ & 131 & $33.85 \%$ & 256 & $66.15 \%$ & LA \\
\hline & Average & 146 & $37.61 \%$ & 241 & $62.39 \%$ & LA \\
\hline
\end{tabular}

Table 2: Frequency and Percentage Scores of Levels of Awareness of Social Health Risks Associated with Egg Donation among Female Undergraduates of Universities in Agbani Education Zone in Enugu State

As shown in Table 2, the average percentage score of (37.61\%) indicates that female undergraduates of universities in Agbani Education Zone in Enugu State had low level of awareness on social health risks associated with egg donation.

\begin{tabular}{|c|c|c|c|c|c|c|}
\hline Sn & Items & \multicolumn{2}{|c|}{ True } & \multicolumn{2}{c|}{ False } & \multirow{2}{*}{ Decision } \\
\cline { 3 - 5 } & Freq. & \% & Freq. & \%A \\
\hline 17 & $\begin{array}{c}\text { loss of sleep is a mental health risk } \\
\text { associated with egg donation }\end{array}$ & 112 & $28.94 \%$ & 275 & $71.06 \%$ & MA \\
\hline 19 & $\begin{array}{c}\text { lack of self-confidence is not a mental } \\
\text { health risk associated with egg } \\
\text { donation }\end{array}$ & 223 & $57.62 \%$ & 164 & $42.38 \%$ & LA \\
\hline 20 & $\begin{array}{c}\text { anxiety over future fertility is a major } \\
\text { mental health risk associated with egg } \\
\text { donation }\end{array}$ & 68 & $17.57 \%$ & 319 & $82.43 \%$ & LA \\
\hline 21 & $\begin{array}{c}\text { victimization is a mental health risk } \\
\text { associated with egg donation }\end{array}$ & 106 & $27.39 \%$ & 281 & $72.61 \%$ & MA \\
\hline 22 & $\begin{array}{c}\text { emotional adjustment is not a mental } \\
\text { health risk associated with egg } \\
\text { donation }\end{array}$ & 188 & $48.58 \%$ & 199 & $51.42 \%$ & LA \\
\hline 23 & $\begin{array}{c}\text { being anxious over one's genetic child } \\
\text { is a mental health issue associated } \\
\text { with egg donation }\end{array}$ & 129 & $33.33 \%$ & 258 & $66.67 \%$ & MA \\
\hline 24 & $\begin{array}{c}\text { psychological discomfort is not a } \\
\text { mental health risk associated with egg } \\
\text { donation }\end{array}$ & 205 & $52.97 \%$ & 182 & $47.03 \%$ & MA \\
\hline $\begin{array}{c}\text { financial stress and frustration are not } \\
\text { a contributing factor that drives young } \\
\text { female to participate in egg donation }\end{array}$ & 189 & $48.84 \%$ & 198 & $51.16 \%$ & \\
\hline Average & 153 & $39.41 \%$ & 234 & $60.60 \%$ & LA \\
\hline
\end{tabular}

Table 3: Frequency and Percentage Scores of Levels of Awareness of Mental Health Risks Associated with

Egg Donation among Female Undergraduates of Universities in Agbani Education Zone in Enugu State 
Data in Table 3 indicate that in overall, $60.60 \%$ of the female undergraduates of universities are not aware of the mental health risks associated with egg donation. Only $39.41 \%$ of them are aware of the health risks associated with egg donation. The respondents however, had low level of awareness on items 17, 19, 20 and 22 with percentage score of $(28.94 \%, 17.57 \%, 27.39 \%)$ and $(33.33 \%)$ respectively. However, they had moderate level of awareness on items $18,21,23$ and 24 with percentage score of $(57.62 \%, 48.58 \%)$ and $(52.97 \%, 48.84 \%)$ respectively.

\begin{tabular}{|c|c|c|c|c|c|c|}
\hline Sn & Items & \multicolumn{2}{|c|}{ True } & \multicolumn{2}{c|}{ False } & Decision \\
\cline { 3 - 5 } & Freq. & \% & Freq. & \% & HA \\
\hline 25 & $\begin{array}{c}\text { egg donation is a very simple } \\
\text { and straight forward } \\
\text { procedure }\end{array}$ & 237 & $61.24 \%$ & 150 & $38.76 \%$ & LA \\
\hline 26 & $\begin{array}{c}\text { egg donation is surgical } \\
\text { removal of egg from a woman }\end{array}$ & 52 & $13.44 \%$ & 335 & $86.56 \%$ & LA \\
\hline 28 & $\begin{array}{c}\text { advertising agents recruits egg } \\
\text { donors }\end{array}$ & 139 & $35.92 \%$ & 248 & $64.08 \%$ & MA \\
\hline 29 & $\begin{array}{c}\text { egg donation is not required } \\
\text { for assisted reproduction }\end{array}$ & 169 & $43.67 \%$ & 218 & $56.33 \%$ & LA \\
\hline 30 & $\begin{array}{c}\text { egg donation is required for } \\
\text { scientific research }\end{array}$ & 87 & $22.48 \%$ & 300 & $77.52 \%$ & MA \\
\hline 31 & $\begin{array}{c}\text { donor's consent letter is not } \\
\text { required before the process of } \\
\text { egg donation }\end{array}$ & 167 & $43.15 \%$ & 220 & $56.85 \%$ & LA \\
\hline 32 & $\begin{array}{c}\text { age is a contributing factor } \\
\text { that drives young female to } \\
\text { participate in egg donation }\end{array}$ & 93 & $24.03 \%$ & 294 & $75.97 \%$ & LA \\
\hline $\begin{array}{c}\text { marital status is a factor for } \\
\text { egg donation }\end{array}$ & 138 & $35.66 \%$ & 249 & $64.34 \%$ & LA \\
\hline
\end{tabular}

Table 4: Frequency and Percentage Scores of Levels of Knowledge of Awareness of Procedures Involved in Egg Donation Among Female Undergraduates of Universities in Agbani Education Zone in Enugu State

In table 4, respondents had low level of awareness on items 26, 27, 29, 31 and 32 with percentage score of $(13.44 \%, 35.92 \%, 22.48 \%, 24.03 \%)$ and (35.66\%) respectively. However, they had moderate level of awareness on items 28 and 30 with percentage score of (43.67\%) and (43.15\%) respectively. They had high level of awareness on item 25 with percentage score of (61.24\%). Therefore, the average percentage score of (34.95\%) showed that female undergraduates of universities in Agbani Education Zone in Enugu State had low level of awareness of procedures involved in egg donation.

\section{Discussions}

From the findings, it was discovered that (57.36\%), had moderate level of awareness of physical health risks associated with egg donation while (37.61\%) had low level of awareness of social health risks associated with egg donation and $(39.41 \%)$ had low level of awareness on mental health risks associated with egg donation. this result is in line with the finding in Owerri Municipal Council of Imo State where it was noted that majority of adults who use electric generator are unaware of the physical health hazards associated with emission from electric generators [6]

Awareness of social health risks associated with egg donation among female undergraduates in Agbani Education Zone in Enugu State, Findings shows that their awareness is low with an average percentage of (37.61\%). This finding is in accord with [6] observation that respondents have low level of awareness of physical health hazard of emission from electric generator. The result is also in line with the submission by [5]who in their study noted that there is need for more awareness that donation of human gametes (sperm, eggs or embryos) creates real dangers for generations yet unborn. It may cause close relatives who are unaware of their genetic relationship or connection to marry each other or somehow, donate sperm or eggs to someone who may be a close relative thereby producing children or grandchildren from their own relative. The reason for the low awareness on social health risks associated with egg donation might be as a result that egg donation is contemporary issue and little or no awareness has been done on it.

Awareness of mental health risks associated with egg donation among female undergraduates in Agbani Education Zone in Enugu State, findings clearly showed that their awareness was equally low with an average percentage of (39.41\%). This is an indication that female undergraduates of universities in Agbani Education zone generally are not aware of the mental health risks associated with egg donation. Strikingly, victimization by donor agencies has moderate grade. This is in contrast with [15] submission that an egg donation cycle costs approximately twenty thousand dollars; only five thousand dollars is likely to go to the egg donor; the rest of the money goes to the clinic and various other administrative fees. This clearly shows victimization or exploitation however, female undergraduates are not aware of the devices because awareness has not been created to expose the menace.

Currently, female undergraduates depend on the information given to them by the egg donor agencies or clinics before participating in egg donation and most times the information might not be comprehensive. Consequently, [11] noted that agency websites often seek to influence potential donors to see donation as natural and fulfilling; and attempt to influence potential donors through both monetary and non-monetary benefits that may inappropriately focus donors 
and recipients on personal gain, rather than on relevant medical considerations. These companies portray egg donors in familiar, reassuring ways to assuage recipients' fears about using reproductive material from strangers, including in donor profiles a range of donor personality characteristics, physical or artistic talents and intellectual abilities, passion and sense of purpose in life, and general temperament or demeanor, and promulgate misunderstandings, making emotional appeals that can distract recipients from appropriate assessments of risks and benefits, and raising issues related to commercialization over professionalism, and eugenics [11].

On awareness of procedure involved in egg donation, the findings shows that an overwhelming majority of the respondents were not familiar with the term 'egg donation for scientific research purposes and 'a little' knew about egg donation for ART. This is rather alarming, as research indicates that female undergraduates of universities may have more simplistic views on egg donation than individuals who are older [2]. [14]Found that openness to donation for research was found to be highly dependent on the participant's fertility status with less-fertile women being more likely to donate their oöcytes for research purposes. However, in this study (65.05\%) had low awareness on the procedure involved with egg donation which indicates possibility of female undergraduates not being aware of the difference between egg donation for infertility and for research purposes. This finding illustrates a lack of awareness, knowledge and understanding about the procedure involved with egg donation process among female undergraduates of universities in Agbani Education Zone. The findings also introduced an important issue of the need for informed consent letters during egg donation. (43.67\%) disputed the need for consent letter in the process of egg donation. however; it is in this consent letter that the health risks are supposed to be spelt out clearly and the compensations therein if the process goes wrong. [11] stated that given the potential limitations of the current model of self regulation of agencies, the present data suggest needs to consider stronger professional guidelines or possible governmental regulations to establish, and enforce higher standards for agencies to follow, regarding advertising to potential donors and recipients, arranging for appropriate informed consent concerning risks and benefits involved, and for quality control. Appropriate informed consent should be obtained from potential egg donors, including the fact that they may learn about mutations or medical problems about which they were unaware, but for which they will not receive treatment as part of this process [11]. Consequently, [16] opined those women who donate their eggs are therefore consenting to invasive medical treatment, where the intention is not to improve their own health, but to benefit someone else. Hence, the donor's consent must also be voluntary, that is, she must have made a free and uncoerced decision to donate her eggs

\section{Conclusion}

It was concluded that there is generally a low level of awareness of health risks, as well as procedures associated with Egg Donation among Female undergraduates of Universities in Agbani Education Zone of Enugu State.

\section{Recommendation}

Based on the findings, it is recommended that there is need to Intensify awareness of health risks associated with egg donation by relevant agencies and departments

- Data Availability: All the necessary data are included in the manuscript

- Conflicting Interests: The authors declare that they have no conflicting interests.

- Funding: This research was completely sponsored by the authors. There was no external funding to the research

- Authors' Contributions: All authors were involved in the conception, design, data collection, analysis and final draft of the manuscript.

- Acknowledgment: The authors are grateful to the research participants who took interest in the study

- Ethical Approval: This study was approved by the health Research Ethics Committee of University of Nigeria Teaching Hospital (reference number: NHREC/05/01/2008B-FWA00002458-1RB00002323/2019).

\section{References}

i. Angel, S.A. (2013). The value of Human Eggs: An Analysis of Risk and Reward in stem cell Research. Berkley Journal of Gender, Law \& Justice, 22(1), 20-34.

ii. Bergh, B., Lampic, A., Lundkuist, A., \&Svanberg, M. (2013). Women attitude to egg donation and sperm donation: A cross cultural study psychology, 31, 5-8

iii. Bernsen, S.P. (2011). Exploring Attitude and Awareness of College Women towards Egg Donation. Unpublished B.Sc Thesis of the State University of Ohio, United State of America, (July, $13^{\text {th }}$.)

iv. Belkin, L. (2011) 'An Egg Donor Responds.' Web blog post. Parenting.blogs.nytimes.com.

v. Ekeke, E.C. \&Uchegbue, C.O. (2010). Solving the problem of infertility among Christians: A bioethical appraisal. American Journal of Social and Management Science, 1(2), 201-208.

vi. Ewuzie, M.A., \&Ibhafidon, A. (2016). Awareness of Physical Health Hazards Associated with Emission from Electrical generator among Adults in Owerri. Nigeria Journal of Health Education, 20 (1) 105-113.

vii. Fadare, J. O, \&Adeniyi, A. A. (2015). Ethical issues in newer Assisted Reproduction Technologies: A view from Nigeria. Niger J clinPract, 18(7), 57-61.

viii. International Society for Stem Cell Research, Task Force (2016). Guidelines for the Conduct of Human Embryonic Stem Cell Research.

ix. Karsjens, K. (2012). Boutique Egg donations: A form of Racism and patriarch. De Paul Journal of Health Care Law. 5(1), 4-10.

x. Kiessling, A. (2014). Compensating Egg Donors: Equal Pay for Equal Time?J. MED. 7, 28-37. 
xi. Klitzman, R. (2016). How old is too old?: Challenges faced by clinicians concerning age-cutoffs for IVF patients .UK : Pub ahead print

xii. Njamanze, C.P. (2008). Trans -Atlantic Human egg trafficking from Nigeria. Paper presented at the meeting of the African Anti-Abortion Coalition Abuja, Nigeria.

xiii. Nworgu, B.U. (2015). Education Research: Basic issues and methodology. Ibadan: Wisdom Publisher.

xiv. Purewal, S. \& van den Akker, O. (2015). British women's attitudes toward oocyte donation: Ethnic differences and altruism. Patient Education and Counseling 64 43-49.

xv. Steinbock, B. (2009). Payment for Egg Donation and Surrogacy. The Mount Sinai Journal of Medicine, 71,255-265.

xvi. Jackson, E (2013). Compensating egg donors. In: Madhok, Sumi, Phillips, Anne and Wilson, Kalpana, (eds.) Gender, Agency and Coercion. Thinking gender in transnational times. Palgrave Macmillan, Basingstoke, UK, pp. 181-194. Available in LSE Research Online http://eprints.lse.ac.uk/53514/ 